Article

\title{
The Effect of Corporate Social Performance on Audit Hours: Moderating Role of the Emphasis of Matter Paragraphs in Audit Report
}

\author{
Hyun Ah Kim ${ }^{1}$ and Nam Chul Jung ${ }^{2, *}$ \\ 1 School of Industrial Management, Korea University of Technology \& Education, 1600 Chungjeol-ro, \\ Byeongcheon-myeon, Dongnam-gu, Cheonan 31253, Korea; kukolo@koreatech.ac.kr \\ 2 School of Business Administration, Hongik University, 94 Wausan-ro, Mapo-gu, Seoul 04066, Korea \\ * Correspondence: jnc1208@hongik.ac.kr
}

Received: 25 December 2019; Accepted: 22 January 2020; Published: 27 January 2020

\begin{abstract}
This study investigated the effect of corporate social performance (CSP) on audit hours and whether the emphasis of matter (EOM) paragraphs in audit report moderates the association between CSP and audit hours. Auditors input audit hours based on the judgement of audit risk related to firm and managerial characteristics. They increase audit hours when they perceive that client companies are riskier; thus, audit hours reflect auditors' perceptions of the firm. Prior studies have shown that high CSP is associated with ethical managers, leading to fewer audit hours. However, auditors' perceptions of CSP can be different depending on their knowledge about firms' potential risks. EOM paragraphs consists of risk-related factors, such as going-concern opinions or litigation and they should be considered when auditors determine that users need to check this information acquired in the auditing process. Therefore, EOM is likely to affect auditors' perceptions of CSP. This study investigates this possibility by examining whether the associations between CSP and audit hours are different in firms with and without EOM paragraphs in audit reports. Using Korean listed companies from 2011 to 2016, we found that CSP has a negative association with audit hours, suggesting that better CSP is related to ethical corporate social responsibility (CSR) in Korea, consistently with the literature. However, CSP is not related to audit hours for firms with EOM paragraphs, possibly indicating that auditors differently interpret CSP based on their knowledge gained in the auditing process. Our findings contribute to the literature by suggesting that EOM paragraphs can be used in distinguishing firms' CSR motivations and that information users should be careful in interpreting CSP.
\end{abstract}

Keywords: corporate social responsibility (CSR); corporate social performance (CSP); audit hours; emphasis of matter (EOM) paragraphs

\section{Introduction}

The Dow Jones Sustainability Index defines sustainability as the assessment of corporate economic, environmental and social performance. Given that corporate social performance (CSP) is the evaluation of corporate environmental and social activities, CSP is an important factor for corporate sustainability. Consistently with this, investors are positive about firms with a high CSP [1]. As the importance of "social responsibility" is emphasized, studies have increasingly analyzed the impact of corporate social responsibility (CSR) activities from various perspectives, such as cost of equity capital, earnings quality, and financial performance [2-6]. They generally find lower cost of equity capital, higher financial reporting quality, and company reputation improvement, supporting the benefits of CSR. However, agency theory suggests that mangers have incentives to pursue their private benefits [7] and Carey 
et al. [8] supported this by showing that opportunistic managers also use CSR to disperse negative public attention. This implies that high CSP is not necessarily related to stakeholder-oriented CSR. Therefore, investors need to distinguish these two contrasting motivations carefully, but this is very difficult because they have little access to private firm and manager information.

Agency theory argues that monitoring mechanisms are effective in mitigating managers' pursuit of private interests [7]. Auditors are an external monitoring mechanism and give credibility to financial information [9]. Previous studies on CSR and auditing mainly focused on this role and found that auditors' assurance increases CSR credibility [10]. However, they also play an information intermediary role through audit reports [11]. Audit opinion is the most important information in audit reports, but it is almost unqualified; thus, auditors use explanatory languages to communicate some important information [11]. The emphasis of matter (EOM) paragraph is one of the explanatory languages and paragraph 8 of International Standard on Auditing (ISA) 706 states, "If the auditor considers it necessary to draw users' attention to a matter presented or disclosed in the financial statements that, in the auditor's judgment, is of such importance that it is fundamental to users' understanding of the financial statements, the auditor shall include an Emphasis of Matter paragraph in the auditor's report provided". EOM paragraphs are related to potential risks such as going-concern opinions or significant transactions and their inclusion is based on the judgement of auditors considering managerial integrity and the firm's financial situation [12]. Therefore, this may indicate the auditor's perception of the firm and managerial risk.

Auditors spend audit hours to decrease audit risk to an acceptable level and to gain assurance that financial statements are not materially distorted [13]. Therefore, audit hours increase (decreases) as audit risk is high (low). Specifically, earnings' management and litigation increase audit hours, but a transparent information environment provided by an ethical manager decreases audit hours [9]. Managerial integrity is an important factor to determine audit risk in auditing processes and CSP reflects the manager's corporate ethics well [14]. Socially responsible firms with high CSP are expected to have stakeholder-oriented managers; thus, auditors are likely to evaluate their audit risks as low, leading to less audit hours [15].

Given that auditors have opportunities to communicate with managers and that they are allowed to access private information of the company, auditors are likely to examine CSR activities based on the knowledge acquired in auditing. Potential risks related to EOM increase the possibility that high CSP is the result of opportunistic CSR because managers of riskier firms have incentives to engage in CSR, dispersing negative attentions [8]. Therefore, auditors are unlikely to evaluate the CSP of firms with EOM paragraphs in the same way as those without EOM paragraphs.

In summary, the purposes of this study are as follows. First, we examined the relationship between firms' CSP and audit hours, indicative of risk level. Secondly, this study investigated whether EOM has a moderating effect on this relationship. Figure 1 depicts our research outline. (Variable definitions are provided in the Section 3.2 Research model and Appendix A.)

Despite the fact that CSR motivations significantly affect corporate sustainability, what information can be used to distinguish between ethical and opportunistic CSR is rarely analyzed in the literature. Even if the EOM provided by auditors is indirect, it has the advantage of being readily available through public audit reports, unlike other information. Therefore, this study has implications that the combination of CSP and EOM may give financial information users a clue to infer which CSR motivations, ethical or opportunistic, lead to a high CSP. This can also be used for investors to distinguish firms whose CSR contributes to their sustainability. Investigating how auditors perceive CSP is also important. If auditors equally evaluate CSP with and without EOM, and the potential risks they find during the audit process, they cannot be seen as appropriately acting with corporate governance and as information intermediaries. 


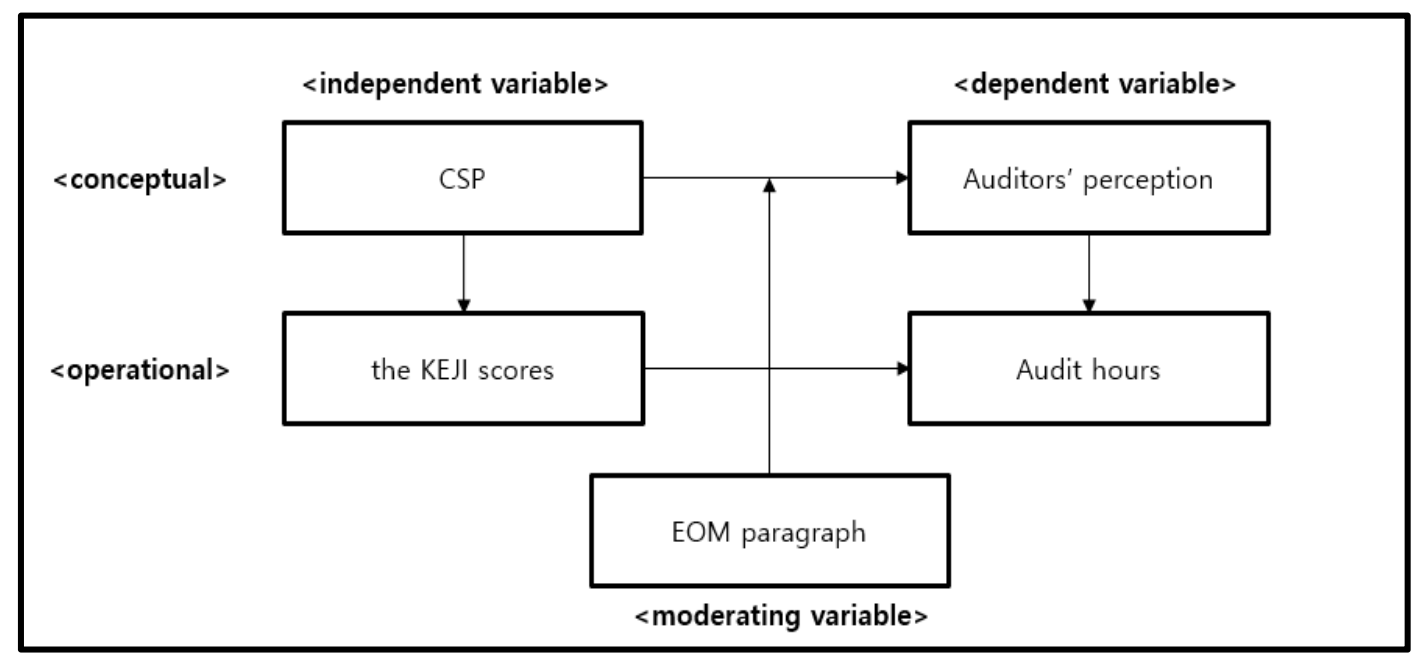

Figure 1. This figure presents the research outline. Variable definitions are provided in the Section 3.2 Research model and Appendix A.

In this study, we used Korean public companies for several reasons. Firstly, Korean firms with high CSP are sometimes associated with wrongdoings. High ranking of Korean CSR consists of large business groups called 'Chaebol' that tend to use CSR to disperse public interests in their past business illegalities [16]. In Korea, better CSP is not necessarily related to ethical managers; thus, it provides an interesting research setting to investigate whether an auditor closely examines a client's CSP based on the knowledge gained in the audit process. Secondly, audit hour data, directly reflecting an auditor's effort and perception of a client firm, are available in Korea. Auditors spend more audit hours responding to audit risk such as litigation risk and misstatement of financial statements $[17,18]$. To identify the way in which auditors perceive CSP or CSR, audit hours are necessary, but most prior studies use audit fees due to the lack of data. This study overcame this limitation using Korean audit hours.

This study contributes to CSR and the audit literature. The result that auditors do not interpret high CSP with EOM paragraphs in audit reports at least positively suggests that information users need to be careful in interpreting CSP. Auditors try to communicate potential risk through EOM paragraphs, but investors mainly focus on the audit opinion and do not consider it in their investment decisions $[11,19]$. Our findings are useful to investors by providing a possibility for EOM to be used in distinguishing ethical managers. In addition, we contribute to the expansion of the literature in CSR from an auditing perspective, which has been noted for a lack of active research, by showing the usefulness of the audit report information on CSR [5,6].

The remainder of the paper is structured as follows. Section 2 reviews the prior literature and develops the hypotheses. Section 3 discusses the research design and the sample selection. Sections 4 and 5 provide empirical results and discussions and implications, respectively.

\section{Prior Research and Hypothesis Development}

\subsection{Prior Literature on Csr and Auditing}

Various studies reported the benefits of CSR activities, such as lower cost of capital, higher financial reporting quality, or more accurate analyst forecast $[3,4,20]$. However, the association between CSR and auditing has not been actively examined [5].

Regarding audit, most studies focused on the role of external auditors as independent assurance of CSR or supplemental or alternate corporate governance [10]. CSR is generally expected to be associated with stakeholder perspective, but it can be used to disguise adverse events, such as pollution; thus, companies have incentives to signal their reliability via assurance or high-quality auditors $[8,10,21,22]$. 
Consistently with this, Chen et al. [22] used the US setting and showed that higher audit fees of CSR firms lend greater credibility to their CSR disclosures. Their findings are consistent with the theoretical intuition suggesting stakeholder orientation of genuine CSR companies. Sun et al. [21] also provided evidence suggesting that higher CSR performance increases the possibility of the selection of industry-specialist auditors. Moreover, Carey et al. [8] interpreted the same result differently, arguing that higher audit fees are the result of increased risk based on the opportunistic behavior of managers. The difference between the two studies may arise from their distinct institutional settings where CSR activities in the US are generally voluntary, whereas Chinese CSR is based on a government initiative $[3,23]$. The finding of $\mathrm{Du}[24]$ that CSR disclosure is strategically used to hide the misconduct of Chinese firms corroborates the argument of Carey et al. [8].

\subsection{Hypothesis Development}

Managerial integrity is an important factor to be considered in the audit process, but the relationship between CSR and auditing has been little investigated [5]. CSR is often considered as stakeholder oriented. In the auditing field, Chen et al. [22] supported this by showing that higher audit fees of CSR firms increase the credibility of their CSR disclosures. However, the positive relationship between CSR disclosure and audit fees can be interpreted as the result of increased risk based on opportunistic behavior such as window dressing [8].

Audit fees enable these two contrasting interpretations because high audit fees reflect both better audit quality and greater audit risk [13,25-27]. Therefore, based on the results of audit fees alone, it is difficult to distinguish whether CSR is related to ethical concerns or opportunistic behavior. Even if auditors sometimes spend more time for higher audit quality [28], actual audit hours are expected to capture auditors' perceptions to audit risks more directly [13]. If managers perform CSR to meet the expectation of stakeholders, the internal control and financial reporting system of the firms could be relatively transparent, which decreases audit hours due to the lower audit risk, resulting in a negative relationship between CSP and audit hours [9]. In contrast, CSR used to disperse public attention arising from misconduct may increase the audit risk, requiring additional audit efforts [8].

Contrarily to the main results, Carey et al. [8] found that high CSP is negatively related to audit fees, indicating a low audit risk. They argued that CSR, backed by a high CSP, is likely to indicate ethical management. Consistently with this, several studies provided evidence that high CSP reflects ethical CSR. Specifically, Du et al. [15] showed that corporate environmental performance has a negative association with modified audit opinions. This is because socially responsible managers are likely to operate the internal control system and the financial reporting system transparently, which decreases audit risk. In addition, Cho and Chun [29] used Korean data and found that socially responsible firms with high CSP curb earnings management. Given that audit risk is positively associated with audit hours [13], we predict that CSP is negatively related to audit hours and set the first hypothesis as follows:

Hypothesis 1: CSP is negatively associated with audit hours.

CSR is an important tool for risk management and corporations can implement CSR risk management in four steps: 1) identifying the risk, 2) evaluating, 3) preparing a strategy, and 4) monitoring [30]. Similarly, regarding audit risk, auditors first identify where risks are expected to exist, then evaluate the risk and prepare strategies to lower the audit risk to an acceptable level. However, auditing cannot eliminate all risks; thus, auditors use audit opinions or explanatory languages to deliver potential risks related to audited firms [13]. The finding that audit reports are used as a performance indicator of CSR activities shows their usefulness in measuring CSR effectiveness [31].

According to ISA 706 paragraph 8, EOM paragraph is used to increase the usefulness of an audit report by drawing the users' attention. EOM paragraphs of Korean public companies are categorized into (1) critical changes in operational environment (e.g., M\&A), (2) significant transactions 
(e.g., related-party transactions), (3) going-concern opinions, (4) litigation, (5) changes in accounting methods, and (6) others [12]. Under the situation that almost all audit opinions are unqualified, the addition of EOM is effective for auditors to communicate risk but firms do not want to include EOM in their audit reports due to their relationship to potential risk [11]. Consistently with this, Czerney et al. [11] provided evidence suggesting that EOM-related matters are likely to be restated, indicating misstatement risk. Similarly, Jung et al. [32] used Korean public firms and showed that audit reports with EOM have a positive association with audit report lag, a proxy of risk.

Auditors detect potential risks in their audit processes and communicate with managers about them. In the process, auditors evaluate managerial corporate ethics and form the expectation of managers' integrity. If auditors perform their auditing properly as an external governance or an information intermediary, they are likely to consider CSP differently, depending on their judgement of managers. A better social performance of the managers whose firms have no EOM in the audit reports is considered as ethical or moral. In contrast, high CSP with EOM is not positively evaluated by auditors. Based on these, we set the second hypothesis as follows:

Hypothesis 2. CSP has no association with audit hours when firms have EOM paragraphs in their audit reports.

\section{Research Design}

\subsection{Corporate Social Performance (CSP)}

Following the literature, we used CSR scores released by The Korea Economic Justice Institute (KEJI) as a proxy for CSP [33,34]. The KEJI annually evaluates Korean public companies in terms of social responsibility and ethical management and publicly provides CSP of the top 200 companies. The CSP of KEJI is consistent with ISO 26000 and Global Reporting Initiatives reporting guidelines, appropriately reflecting Korean economic and social environment, which is often used in the CSR literature.

Its evaluation started in 1991 but continues to refine the method of evaluation. As a result, it has calculated CSR scores (total 100 points) since 2010 based on soundness ( 25 points), fairness ( 20 points), social contribution (15 points), consumer protection (15 points), environmental management (10 points) and employee satisfaction (15 points).

The calculation procedure of the KEJI index is as follows. Firstly, it calculates the actual value of the given indicator according to the formula. Secondly, it converts the actual value to a 100-point scale using the linear interpolation, that is, "value $=$ min value $+\{($ max-value - min value $) \times($ actual value - actual min value) $\} /($ actual max value - actual min value)". Finally, it calculates the final score considering the indicators' weight. For the homogeneity of the KEJI scores, the target year of this study begins in 2011.

\subsection{Research Model}

To test our hypotheses, we specify the regression model (1) considering Cho et al. [35]. The subscripts $i$ and $t$ denote firm and year, respectively.

$$
\begin{aligned}
& \mathrm{LNAH}_{\mathrm{it}}=\alpha_{0}+\alpha_{1} \mathrm{CSP}_{\text {it }}+\alpha_{2} \mathrm{SIZE}_{\mathrm{it}}+\alpha_{3} \mathrm{LEV}_{\mathrm{it}}+\alpha_{4} \mathrm{BIG}_{\mathrm{it}}+\alpha_{5} \mathrm{ROA}_{\mathrm{it}}+\alpha_{6} \mathrm{FOR}_{\mathrm{it}}+\alpha_{7} \mathrm{LAR}_{\mathrm{it}} \\
& +\alpha_{8} \mathrm{LOSS}_{\text {it }}+\alpha_{9} \mathrm{CON}_{\mathrm{it}}+\alpha_{10} \mathrm{ARINV}_{\mathrm{it}}+\alpha_{11} \mathrm{CFO}_{\mathrm{it}}+\alpha_{12} \mathrm{BTM}_{\mathrm{it}}+\alpha_{13} \mathrm{QR}_{\mathrm{it}}+\alpha_{14} \mathrm{GRW}_{\mathrm{it}}+\alpha_{15} \\
& \mathrm{CHN}_{\mathrm{it}}+\text { Year Dummy }+ \text { Industry Dummy }+\varepsilon_{\mathrm{it}}
\end{aligned}
$$

where

$\mathrm{LNAH}=$ The natural logarithm of audit hours;

$\mathrm{CSP}=\mathrm{CSR}$ score released by the KEJI;

SIZE $=$ The natural logarithm of total assets;

LEV $=$ Total liabilities scaled by total assets;

BIG4 $=1$ if the auditor belongs to Big 4 and 0 otherwise; 
$\mathrm{ROA}=$ Net income to beginning total assets;

FOR = Foreign ownership ratio;

$\mathrm{LAR}=$ The ownership ratio of largest shareholders;

LOSS $=1$ if the company experiences loss, 0 otherwise;

$\mathrm{CON}=1$ if the company has consolidated subsidiaries, 0 otherwise;

ARINV = The sum of account receivables and inventories scaled by total assets;

$\mathrm{CFO}=$ Cash flow from operations scaled by total assets;

$\mathrm{BTM}=$ Book value divided by market value;

$\mathrm{QR}=$ Current assets divided by current liabilities;

GRW $=$ Sales growth ratio, which is the percentage of sales increase (decrease) divided by sales in previous year;

$\mathrm{CHN}=1$ if the company changes auditor and 0 otherwise.

The dependent variable, LNAH, indicates audit hours, measured by the natural logarithm of audit hours disclosed in an annual report of Korean public companies. In estimating Equation (1), a significantly negative $\alpha 1$ suggests auditors' perceptions that on average, high CSP is ethical in Korea. To analyze $\mathrm{H} 2$ regarding the effect of EOM on the association between CSP and audit hours, we divide the sample into two depending on whether or not EOM is included in their audit report and estimate equation (1), respectively. If auditors use their knowledge appropriately in evaluating CSP of firms, the negative $\alpha 1$ is expected to disappear in the EOM subsample.

In Equation (1), we control factors influencing audit hours in the prior literature $[13,28,35,36]$. SIZE, measured by the natural logarithm of total assets, is included to control for firm size, which is the most important determinant of audit hours [13]. We predict that larger firms have more audit hours. Since highly leveraged firms (LEV) are risky, we expect auditors to invest additional hours. BIG N auditors (BIG4) spend more audit hours due to litigation risk [37]. The performance (ROA) of the firm affects auditors' efforts. We also include the ownership ratio of foreign investors (FOR) and the largest shareholders (LAR). We also control LOSS since it is related to audit risk. As the complexity of audit affects audit hours, we employ consolidated subsidiaries (CON), and the proportion of account receivables and inventories (ARINV). We expect firms with higher risk to be charged more audit hours [38]. Therefore, we include various risk-relevant factors, such as cash flow (CFO), growth (BTM, GRW), and current ratio (QR). Additionally, we control auditor change (CHN) as it influences audit hours [39]. We predict all the variables except for ROA, corporate governance variables (FOR, LAR), and book-to-market ratio (BTM) as positively related to audit hours. Finally, we controlled the industry (industry dummy) and year-fixed effect (year dummy).

\subsection{Sample Selection}

We used Korean listed firms from 2011 to 2016. The target year begins from 2011 when International Financial Reporting Standards (IFRS) were adopted in Korea. Table 1 provides the sample selection process in Panel A and sample distribution in Panel B, C, and D. As shown in Panel A of Table 1, we start 2225 firm-year observations which are available both the KEJI scores and financial data from DataGuide 5 of FnGuide. We then exclude firm-years from financial industries (145) and lacking information for control variable construction (284). Thus, our final sample consists of 1796 firm-year observations. We derived audit hour data from the TS2000 database, presented by the Korean Listed Companies Association and corporate annual reports disclosed in the Data Analysis, Retrieval and Transfer (DART) system provided by the Korean Financial Supervisory Services (FSS). In addition, we hand-collect EOM paragraphs from audit report of companies and firm-level financial data from DataGuide 5 of FnGuide Company, a popular financial dataset in Korea. 
Table 1. Sample.

\begin{tabular}{|c|c|c|c|c|}
\hline \multicolumn{5}{|c|}{ Panel A: Summary of Sample Selection } \\
\hline \multicolumn{3}{|c|}{ Sample Selection Process } & \multicolumn{2}{|c|}{ \# of firms } \\
\hline \multicolumn{3}{|c|}{ Sample where CSP data are available } & \multicolumn{2}{|c|}{2225} \\
\hline \multicolumn{3}{|c|}{ Deduction: firms in the financial industries } & \multicolumn{2}{|c|}{$(145)$} \\
\hline \multirow{2}{*}{\multicolumn{3}{|c|}{$\begin{array}{l}\text { Deduction: firms with missing audit hours and EOM data } \\
\text { Deduction: firms with missing data }\end{array}$}} & \multirow{2}{*}{\multicolumn{2}{|c|}{$\begin{array}{l}(54) \\
(230)\end{array}$}} \\
\hline & & & & \\
\hline \multicolumn{3}{|c|}{ Final Sample } & \multicolumn{2}{|c|}{1796} \\
\hline \multicolumn{5}{|c|}{ Panel B: By Year and the Presence of EOM Paragraphs } \\
\hline \multirow{2}{*}{ \# of firms } & \multicolumn{2}{|c|}{ Without EOM } & \multicolumn{2}{|c|}{ With EOM } \\
\hline & $\mathrm{N}$ & $\%$ & $\mathrm{~N}$ & $\%$ \\
\hline 2011 & 199 & 85.04 & 35 & 14.96 \\
\hline 2012 & 233 & 74.44 & 80 & 25.56 \\
\hline 2013 & 255 & 82.79 & 53 & 17.21 \\
\hline 2014 & 289 & 85.25 & 50 & 14.75 \\
\hline 2015 & 239 & 85.36 & 41 & 14.64 \\
\hline 2016 & 256 & 79.50 & 66 & 20.50 \\
\hline Total & 1471 & 81.90 & 325 & 18.10 \\
\hline \multicolumn{5}{|c|}{ Panel C: By the Type of EOM Paragraphs } \\
\hline & & & \# of firms & $\%$ \\
\hline $\begin{array}{r}\text { Critical changes in operational e } \\
\text { (e.g., M\&A and ch }\end{array}$ & $\begin{array}{l}\text { hent and } \\
\text { subsidia }\end{array}$ & governance & 39 & 9.73 \\
\hline Significant transactions & ted-par & ons) & 146 & 36.41 \\
\hline Going-co & pinions & & 7 & 1.75 \\
\hline & & & 15 & 3.74 \\
\hline Changes in a & ig meth & & 115 & 28.68 \\
\hline Critical audit matter & r-taking & & 37 & 9.23 \\
\hline Events after rep & ate and & & 42 & 10.47 \\
\hline & & & 401 & 100.00 \\
\hline \multicolumn{5}{|c|}{ Panel D: By Industry } \\
\hline & & & \# of firms & $\%$ \\
\hline Constru & rvices & & 52 & 2.90 \\
\hline Educa & ustry & & 8 & 0.45 \\
\hline Wholesale a & il Busine & & 161 & 8.96 \\
\hline Facilities and Busir & porting & & 15 & 0.84 \\
\hline Food \& A & dations & & 4 & 0.22 \\
\hline Art, Sports and L & elated Ir & & 8 & 0.45 \\
\hline Transpor & usiness & & 69 & 3.84 \\
\hline Electricity, Ga & Tater Sup & & 33 & 1.84 \\
\hline Techn & port & & 41 & 2.28 \\
\hline Man & & & 1312 & 73.05 \\
\hline Publication, Broadcasti & Informa & & 69 & 3.84 \\
\hline & & & 24 & 1.34 \\
\hline & & & 1796 & 100.00 \\
\hline
\end{tabular}

Panel B of Table 1 presents our sample distribution by year and the existence of EOM. In total, $18 \%$ of the sample is firms with EOM. Given that all firm-years included in our final sample have high CSP among public companies, it can be seen that many CSR firms have potential risks. Panel C of Table 1 shows the sample distribution by the type of EOM paragraph. Significant transactions such as related-party transactions (36\%) are the highest, followed by changes in accounting methods $(29 \%)$ and critical changes in operational environment and corporate governance (10\%). Since a company can 
have two or more EOM paragraphs, the total number of observations is over 325 firm-year observations in Panel B of Table 1. As presented in Panel D of Table 1, approximately 82\% of our samples belongs to Manufacturing (73\%) and Wholesale and Retail (9\%).

\section{Empirical Results}

\subsection{Descriptive Statistics and Correlations}

Table 2 reports descriptive statistics for the variables used in the analysis. All continuous variables in our study are winsorized at the upper and lower $1 \%$ tails of distribution. The mean and median values of LNAH are 7.240 and 7.048, respectively, which are 1394 and 1151 in terms of audit hours, respectively. The mean (median) and standard deviation of CSP are 62.029 (62.019) and 3.001 , respectively. On average, the debt-to-asset ratio (LEV) is about $39.3 \%$, and about $67.5 \%$ of our dataset appoint BIG4 as auditor. The average values for FOR and LAR suggest about 9.7\% and 45.0\%, respectively. The means of current ratio (QR) and auditor change ratio (CHN) are $222.4 \%$ and $11.2 \%$, respectively. About $18.1 \%$ of our sample reports EOM paragraphs (EOM) in their audit reports.

Table 2. Descriptive Statistics.

\begin{tabular}{ccccccccc}
\hline Variable & $\mathbf{N}$ & Mean & std. & MIN & $\mathbf{2 5 \%}$ & Median & $\mathbf{7 5 \%}$ & MAX \\
\hline LNAH & 1796 & 7.240 & 0.837 & 5.817 & 6.695 & 7.048 & 7.625 & 10.238 \\
CSP & 1796 & 62.029 & 3.001 & 54.862 & 59.937 & 62.019 & 64.119 & 69.225 \\
SIZE & 1796 & 19.753 & 1.285 & 17.415 & 18.905 & 19.575 & 20.381 & 23.510 \\
LEV & 1796 & 0.393 & 0.181 & 0.061 & 0.250 & 0.385 & 0.536 & 0.817 \\
BIG4 & 1796 & 0.675 & 0.469 & 0.000 & 0.000 & 1.000 & 1.000 & 1.000 \\
ROA & 1796 & 0.048 & 0.047 & -0.054 & 0.020 & 0.041 & 0.069 & 0.210 \\
FOR & 1796 & 0.097 & 0.125 & 0.000 & 0.011 & 0.041 & 0.137 & 0.527 \\
LAR & 1796 & 0.450 & 0.157 & 0.112 & 0.334 & 0.461 & 0.559 & 0.796 \\
LOSS & 1796 & 0.047 & 0.212 & 0.000 & 0.000 & 0.000 & 0.000 & 1.000 \\
CON & 1796 & 0.707 & 0.455 & 0.000 & 0.000 & 1.000 & 1.000 & 1.000 \\
ARINV & 1796 & 0.302 & 0.153 & 0.015 & 0.190 & 0.295 & 0.399 & 0.707 \\
CFO & 1796 & 0.064 & 0.071 & -0.124 & 0.027 & 0.062 & 0.101 & 0.276 \\
BTM & 1796 & 1.216 & 0.740 & 0.157 & 0.680 & 1.045 & 1.582 & 3.666 \\
QR & 1796 & 2.224 & 2.202 & 0.342 & 1.092 & 1.563 & 2.497 & 12.148 \\
GRW & 1796 & 0.065 & 0.246 & -0.279 & -0.032 & 0.035 & 0.108 & 0.992 \\
CHN & 1796 & 0.112 & 0.316 & 0.000 & 0.000 & 0.000 & 0.000 & 1.000 \\
EOM & 1796 & 0.181 & 0.385 & 0.000 & 0.000 & 0.000 & 0.000 & 1.000 \\
\hline
\end{tabular}

Notes: Appendix A provides variable definitions. All continuous variables are winsorized in the (1\%, 99\%) range.

Table 3 presents the Pearson correlations of our key variables. CSP is positively and significantly correlated with LNAH. CSP represents a positive correlation with SIZE, BIG4, ROA, FOR, ARINV, CFO and GRW at the 1\% level. By contrast, CSP shows a negative association with LEV, LAR and BTM at the $1 \%$ level. LNAH is positively associated to risk factors such as SIZE, LEV, and LOSS in the current period. FOR shows a positive correlation with audit hours, while LAR shows a negative correlation with audit hours. Meanwhile, firm-years with EOM paragraphs are positively correlated with LEV and LOSS, indicating the high possibility of potential risks. In sum, the correlation results, the positive association between CSP and LNAH and the EOM's negative relationship with LNAH appear somewhat contrary to our prediction. However, as shown in Table 3, CSP, EOM and LNAH are significantly associated with SIZE. Therefore, it is too early to conclude based on the univariate results alone without controlling for firm-level characteristics. 
Table 3. Pearson correlations.

\begin{tabular}{|c|c|c|c|c|c|c|c|c|c|c|c|c|c|c|c|c|}
\hline Variable & LNAH & $C S P$ & SIZE & $L E V$ & BIG4 & $R O A$ & FOR & $L A R$ & LOSS & $C O N$ & ARINV & CFO & BTM & $Q R$ & GRW & $C H N$ \\
\hline CSP & $\begin{array}{l}0.092 \\
0.000\end{array}$ & & & & & & & & & & & & & & & \\
\hline \multirow[t]{2}{*}{ SIZE } & 0.790 & 0.162 & & & & & & & & & & & & & & \\
\hline & 0.000 & 0.000 & & & & & & & & & & & & & & \\
\hline \multirow[t]{2}{*}{$L E V$} & 0.197 & -0.119 & 0.216 & & & & & & & & & & & & & \\
\hline & 0.000 & 0.000 & 0.000 & & & & & & & & & & & & & \\
\hline \multirow[t]{2}{*}{ BIG4 } & 0.435 & 0.079 & 0.411 & 0.069 & & & & & & & & & & & & \\
\hline & 0.000 & 0.001 & 0.000 & 0.003 & & & & & & & & & & & & \\
\hline \multirow[t]{2}{*}{$R O A$} & 0.012 & 0.223 & 0.034 & -0.279 & 0.041 & & & & & & & & & & & \\
\hline & 0.624 & 0.000 & 0.147 & 0.000 & 0.079 & & & & & & & & & & & \\
\hline \multirow[t]{2}{*}{ FOR } & 0.450 & 0.246 & 0.491 & -0.157 & 0.231 & 0.282 & & & & & & & & & & \\
\hline & 0.000 & 0.000 & 0.000 & 0.000 & 0.000 & 0.000 & & & & & & & & & & \\
\hline \multirow[t]{2}{*}{$L A R$} & -0.115 & -0.298 & -0.065 & -0.072 & 0.021 & -0.017 & -0.219 & & & & & & & & & \\
\hline & 0.000 & 0.000 & 0.006 & 0.002 & 0.380 & 0.465 & 0.000 & & & & & & & & & \\
\hline \multirow[t]{2}{*}{ LOSS } & 0.044 & -0.072 & -0.005 & 0.160 & -0.024 & -0.400 & -0.073 & -0.062 & & & & & & & & \\
\hline & 0.062 & 0.002 & 0.832 & 0.000 & 0.301 & 0.000 & 0.002 & 0.009 & & & & & & & & \\
\hline \multirow[t]{2}{*}{$C O N$} & 0.353 & 0.016 & 0.283 & 0.074 & 0.086 & -0.076 & 0.157 & -0.112 & 0.034 & & & & & & & \\
\hline & 0.000 & 0.505 & 0.000 & 0.002 & 0.000 & 0.001 & 0.000 & 0.000 & 0.150 & & & & & & & \\
\hline \multirow[t]{2}{*}{ ARINV } & -0.190 & 0.067 & -0.208 & 0.224 & -0.051 & 0.064 & -0.146 & -0.029 & -0.047 & -0.067 & & & & & & \\
\hline & 0.000 & 0.004 & 0.000 & 0.000 & 0.031 & 0.007 & 0.000 & 0.222 & 0.047 & 0.005 & & & & & & \\
\hline \multirow[t]{2}{*}{ CFO } & 0.067 & 0.150 & 0.092 & -0.177 & 0.049 & 0.452 & 0.260 & -0.016 & -0.131 & -0.072 & -0.137 & & & & & \\
\hline & 0.005 & 0.000 & 0.000 & 0.000 & 0.040 & 0.000 & 0.000 & 0.511 & 0.000 & 0.002 & 0.000 & & & & & \\
\hline \multirow[t]{2}{*}{ BTM } & -0.155 & -0.150 & -0.071 & -0.015 & -0.069 & -0.348 & -0.206 & 0.159 & 0.092 & -0.053 & -0.036 & -0.210 & & & & \\
\hline & 0.000 & 0.000 & 0.003 & 0.517 & 0.004 & 0.000 & 0.000 & 0.000 & 0.000 & 0.025 & 0.133 & 0.000 & & & & \\
\hline \multirow[t]{2}{*}{$Q R$} & -0.151 & 0.058 & -0.177 & -0.623 & -0.073 & 0.107 & 0.121 & -0.053 & -0.024 & -0.067 & -0.116 & 0.020 & -0.023 & & & \\
\hline & 0.000 & 0.015 & 0.000 & 0.000 & 0.002 & 0.000 & 0.000 & 0.025 & 0.302 & 0.005 & 0.000 & 0.399 & 0.338 & & & \\
\hline \multirow[t]{2}{*}{ GRW } & -0.007 & 0.070 & -0.030 & 0.098 & -0.041 & 0.167 & -0.019 & -0.024 & -0.079 & -0.032 & 0.105 & -0.004 & -0.112 & -0.092 & & \\
\hline & 0.780 & 0.003 & 0.197 & 0.000 & 0.083 & 0.000 & 0.431 & 0.301 & 0.001 & 0.173 & 0.000 & 0.880 & 0.000 & 0.000 & & \\
\hline \multirow[t]{2}{*}{ CHN } & -0.031 & -0.002 & -0.035 & 0.047 & -0.065 & -0.033 & -0.067 & -0.029 & 0.029 & -0.058 & -0.002 & -0.022 & -0.033 & -0.028 & 0.020 & \\
\hline & 0.185 & 0.943 & 0.138 & 0.049 & 0.006 & 0.164 & 0.005 & 0.214 & 0.227 & 0.015 & 0.928 & 0.354 & 0.157 & 0.233 & 0.391 & \\
\hline \multirow{2}{*}{ EOM } & -0.101 & -0.021 & -0.122 & 0.069 & -0.239 & -0.043 & -0.080 & -0.032 & 0.086 & -0.057 & -0.043 & -0.055 & -0.002 & 0.004 & 0.032 & 0.011 \\
\hline & 0.000 & 0.378 & 0.000 & 0.004 & 0.000 & 0.071 & 0.001 & 0.176 & 0.000 & 0.016 & 0.071 & 0.019 & 0.948 & 0.878 & 0.175 & 0.635 \\
\hline
\end{tabular}

Notes: Appendix A provides variable definitions; Values below the correlation coefficients represent p-values. 


\subsection{The Association between CSP and Audit Hours (Hypothesis 1)}

Table 4 reports our empirical result regarding Hypothesis 1 . To correct for potential correlation of regression residuals, we report robust t-statistics adjusted for firm-level clustering, following Petersen [40].

Table 4. The association between CSP and audit hours.

\begin{tabular}{|c|c|c|c|c|}
\hline \multirow{2}{*}{$\begin{array}{l}L N A H= \\
\text { Variables }\end{array}$} & \multicolumn{4}{|c|}{$\begin{array}{c}\alpha_{0}+\alpha_{1} C S P+\alpha_{2} S I Z E+\alpha_{3} L E V+\alpha_{4} B I G 4+\alpha_{5} R O A+\alpha_{6} F O R+\alpha_{7} L A R+\alpha_{8} L O S S \\
+\alpha_{9} C O N+\alpha_{10} A R I N V+\alpha_{11} C F O+\alpha_{12} B T M+\alpha_{13} Q R+\alpha_{14} G R W+\alpha_{15} C H N \\
+ \text { Year Dummy }+ \text { Industry Dummy }+\varepsilon\end{array}$} \\
\hline & Pred. sign & & & t-statistics \\
\hline Intercept & $+/-$ & -0.696 & & -1.43 \\
\hline CSP & - & -0.013 & $* *$ & -2.23 \\
\hline SIZE & + & 0.429 & $* * *$ & 24.13 \\
\hline LEV & + & 0.105 & & 0.82 \\
\hline BIG4 & + & 0.235 & $* * *$ & 6.88 \\
\hline$R O A$ & - & -0.107 & & -0.28 \\
\hline FOR & $+/-$ & 0.442 & $* * *$ & 2.81 \\
\hline$L A R$ & $+/-$ & -0.213 & * & -1.94 \\
\hline LOSS & + & 0.164 & $* * *$ & 2.73 \\
\hline CON & + & 0.235 & $* * *$ & 6.73 \\
\hline ARINV & + & -0.100 & & -0.75 \\
\hline CFO & + & -0.060 & & -0.30 \\
\hline BTM & - & -0.065 & $* * *$ & -3.01 \\
\hline$Q R$ & + & -0.009 & & -1.21 \\
\hline$\widehat{G R W}$ & + & 0.102 & * & 1.85 \\
\hline $\mathrm{CHN}$ & + & 0.009 & & 0.28 \\
\hline Year Dummy & & & Included & \\
\hline Industry Dummy & & & Included & \\
\hline Adj. $R^{2}$ & & & 0.696 & \\
\hline F-statistics & & & $122.05^{* * *}$ & \\
\hline $\mathrm{N}$ & & & 1796 & \\
\hline Clustering & & & Firm & \\
\hline Max VIF & & & 2.46 & \\
\hline
\end{tabular}

Notes: Appendix A provides variable definitions; Standard errors are corrected at firm levels. ${ }^{* * *},{ }^{* *},{ }^{*}$ imply two-tailed significance at $1 \%, 5 \%$, and $10 \%$ levels, respectively.

As shown in Table 4, the adjusted $\mathrm{R}^{2}$ value (0.696), F-statistics (122.05), and low VIF indicate good fit of our research model. Supporting Hypothesis 1, we found that CSP is negatively associated with LNAH at the $5 \%$ level of significance (coefficient $=-0.013$; $\mathrm{t}$-statistics value $=-2.23$ ), which suggests that the auditors tend to consider firms with a high CSP as having a low audit risk, resulting in fewer audit hours.

In general, the coefficients of control variables are in line with our predictions. LNAH shows a positive association with SIZE, BIG4, LOSS, CON and GRW, while it is negatively related to ROA and BTM. In terms of corporate governance, LNAH is positively correlated with FOR and negatively related to LAR.

If a high CSP reflects ethically motivated CSR, it should be related to a better financial reporting quality and a greater firm value. For the robustness of our result, we additionally examined these in the followings.

First, we investigated the association between CSP and the performance matched discretionary accruals (PMDA) following a previous study and reported the result in Table 5 [41,42]. CSP has a significantly negative relationship to PMDA (FRQ) (coefficient $=-0.002 ; \mathrm{t}$-statistics value $=-5.71$ ). Given that high values of PMDA indicate low financial reporting quality, the result supports that that firms with high CSP are ethical on average. 
Table 5. The association between CSP and Financial Reporting Quality.

\begin{tabular}{|c|c|c|c|c|}
\hline \multirow{3}{*}{$\begin{array}{c}F R Q= \\
\text { Variables } \\
\text { Intercept }\end{array}$} & \multicolumn{4}{|c|}{$\begin{array}{c}\alpha 0+\alpha 1 C S P+\alpha 2 S I Z E+\alpha 3 L E V+\alpha 4 B I G 4+\alpha 5 R O A+\alpha 6 F O R+\alpha 7 L A R+\alpha 8 L 1 T A C \\
+\alpha 9 C F O+Y e a r D u m m y+\text { Industry Dummy }+\varepsilon\end{array}$} \\
\hline & \multirow{2}{*}{$\begin{array}{c}\text { Pred. sign } \\
+/-\end{array}$} & \multicolumn{2}{|c|}{ Coefficient } & \multirow{2}{*}{$\frac{\text { t-statistics }}{29.08}$} \\
\hline & & 0.596 & $* * *$ & \\
\hline CSP & - & -0.002 & $* * *$ & -5.71 \\
\hline SIZE & - & -0.020 & $* * *$ & -28.32 \\
\hline$L E V$ & $+/-$ & -0.006 & & -1.30 \\
\hline BIG4 & - & -0.005 & $* * *$ & -3.12 \\
\hline FOR & - & -0.038 & $* * *$ & -7.94 \\
\hline$L A R$ & $+/-$ & 0.015 & & 1.54 \\
\hline L1TAC & - & 1.243 & $* * *$ & 72.65 \\
\hline$R O A$ & - & -1.088 & $* * *$ & -96.42 \\
\hline CFO & + & 0.596 & $* * *$ & 29.08 \\
\hline Year Dummy & & & Included & \\
\hline Industry Dummy & & & Included & \\
\hline Adj. R2 & & & 0.883 & \\
\hline F-statistics & & & $513.84^{* * *}$ & \\
\hline $\mathrm{N}$ & & & 1796 & \\
\hline Clustering & & & Firm & \\
\hline Max VIF & & & 1.75 & \\
\hline
\end{tabular}

Notes: Appendix A provides variable definitions; Standard errors are corrected at firm levels. ${ }^{* * *},{ }^{* *},{ }^{*}$ imply two-tailed significance at $1 \%, 5 \%$, and $10 \%$ levels, respectively.

Secondly, we tested whether high CSP contributes to firm value (Tobin's q) based on prior research [43] and show the result in Table 6. As shown in Table 6, the coefficient of CSP is 0.025, significant at the level of $1 \%$ (t-statistics value $=3.98$ ). This is another evidence of Korean CSP from an ethical perspective, consistent with the literature [29]. Taken together, CSR has both aspects, ethical and opportunistic, but firms with high CSP are likely to have more ethical characteristics of CSR. Auditors interpret this properly as low audit risk and decrease audit hours responding to this.

Table 6. The relationship between CSP and Firm Value.

\begin{tabular}{|c|c|c|c|c|}
\hline \multirow{2}{*}{$\begin{array}{c}T Q= \\
\text { Variables }\end{array}$} & \multicolumn{4}{|c|}{$\begin{array}{c}\alpha_{0}+\alpha_{1} C S P+\alpha_{2} S I Z E+\alpha_{3} L E V+\alpha_{4} B I G 4+\alpha_{5} R O A+\alpha_{6} F O R+\alpha_{7} L A R+\text { Year } \\
\text { Dummy }+ \text { Industry Dummy }+\varepsilon\end{array}$} \\
\hline & Pred. sign & & & t-statistics \\
\hline Intercept & $+/-$ & -0.375 & & -0.61 \\
\hline CSP & + & 0.025 & $* * *$ & 3.98 \\
\hline SIZE & + & -0.045 & & -1.62 \\
\hline$L E V$ & $+/+$ & 0.701 & $* * *$ & 4.24 \\
\hline BIG4 & + & 0.044 & & 0.97 \\
\hline$R O A$ & + & 4.813 & $* * *$ & 5.91 \\
\hline FOR & + & 1.119 & $* * *$ & 2.78 \\
\hline$L A R$ & $+/-$ & -0.286 & * & -1.75 \\
\hline Year Dummy & & & Included & \\
\hline Industry Dummy & & & Included & \\
\hline Adj. $R^{2}$ & & & 0.299 & \\
\hline F-statistics & & & $31.24^{* * *}$ & \\
\hline $\mathrm{N}$ & & & 1796 & \\
\hline Clustering & & & Firm & \\
\hline Max VIF & & & 1.76 & \\
\hline
\end{tabular}

Notes: Appendix A provides variable definitions; Standard errors are corrected at firm levels. ${ }^{* * *},{ }^{* *},{ }^{*}$ imply two-tailed significance at $1 \%, 5 \%$, and $10 \%$ levels, respectively. 


\subsection{The Effect of EOM on the Association between CSP and Audit Hours (Hypothesis 2)}

Table 7 presents the results of Hypothesis 2. We found that the results in Table 4, the negative association between CSR and LNAH, remains in the subsample without EOM (coefficient $=-0.014$; $\mathrm{t}$-statistics value $=-2.20$ ) but disappears in firm-years with EOM (coefficient $=-0.006$; $t$-statistics value $=-0.57$ ) consistently with Hypothesis 2 . This finding indicates that auditors interpret CSP differently depending on the inclusion of EOM paragraphs. As shown by Czerney et al. [9], the EOM paragraphs are used by auditors to communicate the underlying risk, possibly requiring restatement in the future. Therefore, auditors may distinguish CSR motivations based on EOM paragraphs because they understand that managers with EOM can engage in CSR activities based on opportunistic incentives to disperse public attention related to potential risk. Taken together, the results in Table 7 suggest that auditors evaluate audit risk related to CSR differently considering the potential risk, and EOM can be an indicator of opportunistic CSR motivation.

Table 7. The effect of EOM paragraphs on the association between CSP and audit hours.

\begin{tabular}{|c|c|c|c|c|c|c|c|}
\hline \multirow{4}{*}{ Variables } & \multicolumn{7}{|c|}{$\begin{array}{c}\alpha_{0}+\alpha_{1} C S P+\alpha_{2} S I Z E+\alpha_{3} L E V+\alpha_{4} B I G 4+\alpha_{5} R O A+\alpha_{6} F O R+\alpha_{7} L A R+\alpha_{8} L O S S+\alpha_{9} C O N \\
+\alpha_{10} A R I N V+\alpha_{11} C F O+\alpha_{12} B T M+\alpha_{13} Q R+\alpha_{14} G R W+\alpha_{15} C H N+\text { Year Dummy }+ \text { Industry } \\
\text { Dummy }+\varepsilon\end{array}$} \\
\hline & \multirow{3}{*}{$\begin{array}{l}\text { Predicted } \\
\text { Sign }\end{array}$} & \multicolumn{6}{|c|}{ Dependent Variables: $L N A H$} \\
\hline & & \multicolumn{3}{|c|}{ Sample with EOM } & \multicolumn{3}{|c|}{ Sample without EOM } \\
\hline & & Coefficient & & t-statistics & Coefficient & & t-statistics \\
\hline Intercept & $+/-$ & -0.255 & & -0.23 & -0.843 & * & -1.65 \\
\hline CSP & - & -0.006 & & -0.57 & -0.014 & $* *$ & -2.20 \\
\hline SIZE & + & 0.365 & $* * *$ & 7.66 & 0.439 & $* * *$ & 23.99 \\
\hline$L E V$ & + & 0.523 & $* *$ & 2.18 & -0.017 & & -0.12 \\
\hline BIG4 & + & 0.311 & $* * *$ & 4.62 & 0.224 & $* * *$ & 5.84 \\
\hline$R O A$ & - & -1.007 & & -1.32 & -0.021 & & -0.05 \\
\hline FOR & $+/-$ & -0.021 & & -0.07 & 0.541 & $* * *$ & 3.14 \\
\hline$L A R$ & $+/-$ & -0.053 & & -0.22 & -0.235 & $* *$ & -1.97 \\
\hline LOSS & + & -0.119 & & -1.12 & 0.215 & $* * *$ & 2.95 \\
\hline CON & + & 0.326 & $* * *$ & 4.94 & 0.219 & $* * *$ & 5.60 \\
\hline ARINV & + & -0.517 & $* *$ & -2.18 & -0.024 & & -0.16 \\
\hline CFO & + & -0.060 & & -0.13 & -0.011 & & -0.05 \\
\hline BTM & - & -0.036 & & -1.08 & -0.065 & $* * *$ & -2.61 \\
\hline$Q R$ & + & 0.017 & & 1.49 & -0.018 & $* *$ & -2.31 \\
\hline$\widetilde{G R W}$ & + & 0.107 & & 1.40 & 0.088 & & 1.30 \\
\hline $\mathrm{CHN}$ & + & -0.046 & & -0.56 & 0.023 & & 0.69 \\
\hline Year Dummy & & \multicolumn{3}{|c|}{ Included } & \multicolumn{3}{|c|}{ Included } \\
\hline Industry Dummy & & \multicolumn{3}{|c|}{ Included } & \multicolumn{3}{|c|}{ Included } \\
\hline Adj. $\mathrm{R}^{2}$ & & \multicolumn{3}{|c|}{0.709} & \multicolumn{3}{|c|}{0.704} \\
\hline F-statistics & & \multicolumn{3}{|c|}{$23.90^{* * *}$} & \multicolumn{3}{|c|}{$104.04^{* * *}$} \\
\hline $\mathrm{N}$ & & \multicolumn{3}{|c|}{325} & \multicolumn{3}{|c|}{1471} \\
\hline Clustering & & \multicolumn{3}{|c|}{ Firm } & \multicolumn{3}{|c|}{ Firm } \\
\hline Max VIF & & \multicolumn{3}{|c|}{2.75} & \multicolumn{3}{|c|}{2.55} \\
\hline
\end{tabular}

Notes: Appendix A provides variable definitions; Standard errors are corrected at firm levels. ${ }^{* * *},{ }^{* *},{ }^{*}$ imply two-tailed significance at $1 \%, 5 \%$, and $10 \%$ levels, respectively.

\subsection{Additional Analysis}

\subsubsection{Big4 Auditors}

Prior studies [41,44] showed that auditors spend additional hours to maintain their reputation capital and audit quality, indicating that increased audit hours are related to greater audit quality. To control for this possibility, we confine our sample to Big4 auditors, which are relatively homogeneous in terms of reputation, audit quality and audit hours, and repeat our regression analysis. 
Using 1212 firm-year observations with BIG4 auditor, Table 8 shows that the coefficient (coefficient $=-0.015$; t-statistics value $=-2.03$ ) of CSP is negatively associated with LNAH in the full sample at the $5 \%$ level. The significantly negative relationship between CSR and LNAH is apparent only in the sample without EOM paragraphs (coefficient $=-0.014$; $\mathrm{t}$-statistics value $=-1.77$ ) consistent with the results in Tables 4 and 7.

Table 8. Additional analysis confining the sample with big4 auditor.

\begin{tabular}{|c|c|c|c|c|c|c|c|c|c|c|}
\hline \multirow{4}{*}{ Variables } & \multicolumn{10}{|c|}{$\begin{array}{c}\alpha_{0}+\alpha_{1} C S P+\alpha_{2} S I Z E+\alpha_{3} L E V+\alpha_{4} R O A+\alpha_{5} F O R+\alpha_{6} L A R+\alpha_{7} L O S S+\alpha_{8} C O N+\alpha_{9} A R I N V+ \\
\alpha_{10} C F O+\alpha_{11} B T M+\alpha_{12} Q R+\alpha_{13} G R W+\alpha_{14} C H N+\text { Year Dummy }+ \text { Industry Dummy }+\varepsilon\end{array}$} \\
\hline & \multirow{3}{*}{$\begin{array}{l}\text { Predicted } \\
\text { Sign }\end{array}$} & \multicolumn{9}{|c|}{ Dependent Variables: LNAH } \\
\hline & & \multicolumn{3}{|c|}{ Full Sample } & \multicolumn{3}{|c|}{ Sample with EOM } & \multicolumn{3}{|c|}{ Sample without EOM } \\
\hline & & Coeff & & t-stat & Coeff & & t-stat & Coeff & & t-stat \\
\hline Intercept & $+/-$ & -0.899 & & -1.43 & -1.859 & & -1.04 & -0.980 & & -1.56 \\
\hline CSP & - & -0.015 & $* *$ & -2.03 & -0.004 & & -0.25 & -0.014 & * & -1.77 \\
\hline SIZE & + & 0.461 & $* * *$ & 22.69 & 0.430 & $* * *$ & 5.99 & 0.461 & $* * *$ & 22.77 \\
\hline$L E V$ & + & 0.122 & & 0.76 & 0.844 & * & 1.86 & 0.050 & & 0.29 \\
\hline$R O A$ & - & -0.032 & & -0.06 & -1.662 & & -1.16 & 0.314 & & 0.57 \\
\hline FOR & $+/-$ & 0.399 & $* *$ & 2.11 & -0.231 & & -0.47 & 0.456 & $* *$ & 2.24 \\
\hline$L A R$ & $+/-$ & -0.433 & $* * *$ & -2.95 & 0.049 & & 0.10 & -0.448 & $* * *$ & -2.89 \\
\hline LOSS & + & 0.234 & $* * *$ & 2.97 & -0.244 & & -1.04 & 0.301 & $* * *$ & 3.58 \\
\hline $\mathrm{CON}$ & + & 0.227 & $* * *$ & 5.13 & 0.303 & $* *$ & 2.44 & 0.218 & $* * *$ & 4.57 \\
\hline ARINV & + & -0.072 & & -0.40 & -1.188 & $* *$ & -2.35 & -0.029 & & -0.15 \\
\hline CFO & + & 0.113 & & 0.41 & 0.721 & & 0.88 & -0.018 & & -0.07 \\
\hline BTM & - & -0.075 & $* * *$ & -2.80 & -0.022 & & -0.34 & -0.073 & $* *$ & -2.52 \\
\hline$Q R$ & + & -0.022 & $* * *$ & -2.66 & 0.041 & & 1.86 & -0.028 & $* * *$ & -3.27 \\
\hline GRW & + & 0.095 & & 1.05 & 0.193 & & 1.08 & 0.094 & * & 0.91 \\
\hline $\mathrm{CHN}$ & + & -0.029 & & -0.70 & -0.167 & & -1.21 & -0.010 & & -0.22 \\
\hline Year Dummy & & \multicolumn{3}{|c|}{ Included } & \multicolumn{3}{|c|}{ Included } & \multicolumn{3}{|c|}{ Included } \\
\hline Industry Dummy & & \multicolumn{3}{|c|}{ Included } & \multicolumn{3}{|c|}{ Included } & \multicolumn{3}{|c|}{ Included } \\
\hline Adj. $R^{2}$ & & \multicolumn{3}{|c|}{0.674} & \multicolumn{3}{|c|}{0.722} & \multicolumn{3}{|c|}{0.685} \\
\hline F-statistics & & \multicolumn{3}{|c|}{$76.43^{* * *}$} & \multicolumn{3}{|c|}{$10.49^{* * *}$} & \multicolumn{3}{|c|}{$70.48^{* * *}$} \\
\hline $\mathrm{N}$ & & \multicolumn{3}{|c|}{1,212} & \multicolumn{3}{|c|}{142} & \multicolumn{3}{|c|}{1,070} \\
\hline Clustering & & \multicolumn{3}{|c|}{ Firm } & \multicolumn{3}{|c|}{ Firm } & \multicolumn{3}{|c|}{ Firm } \\
\hline Max VIF & & \multicolumn{3}{|c|}{2.46} & \multicolumn{3}{|c|}{3.37} & \multicolumn{3}{|c|}{2.49} \\
\hline
\end{tabular}

\subsubsection{Further Analysis of Samples Except 2011, 2012 and 2013}

In December 2012, the Financial Supervisory Committee of Korea approved International Standard on Auditing (ISA) adoption after 2014. Therefore, the expressions in the EOM paragraphs of the audit report after 2014 appear partially changed from earlier expressions. Un-tabulated results excluding the years 2011, 2012 and 2013 do not qualitatively differ from those indicated in Tables 4 and 5.

\section{Discussion and Implications}

Previous studies focused on the role of auditors as an external monitoring mechanism by examining whether firms with better CSP appoint auditors with high audit quality or whether auditors provide credibility to CSR $[10,21]$. Unlike this, this study investigates auditors' role as an CSP related information intermediary by using EOM as a proxy for auditors' perception to a potential firm risk. The results of the study show that auditors perceive and respond to the firm's CSP by increasing (or decreasing) their audit hours and the relationship is discriminated depending on whether the EOM paragraphs are included in audit reports. The findings of the current study contribute to the literature as follows.

First, the negative association between CSP and audit hours corroborates with the previous findings, indicating that high CSP is the result from ethical CSR in Korea. Prior studies tried to use audit fees and to identify which motivation, ethical or opportunistic, is related to CSR, but because 
audit fees reflect risk premium as well as auditors' behavior or effort responding to audit risk, they is not sufficient to examine how auditors evaluate CSR $[8,9,22]$. The first finding of this study adds more empirical evidence in Korea about the relationship between CSP and ethical CSR activities and shows that auditors evaluate firms with high CSP ethically on average.

Secondly, the findings of this study stress the role of audit report information as an identifier of CSR motivations, indicating that auditors reviewing a firm's private information and managerial ethics differently interpret high CSP with and without EOM paragraphs. This result implies that firms with potential risks are unlikely to engage in ethical CSR activities; thus, financial information users including investors need to carefully check the information provided by the auditors and evaluate the firm's CSP. Chen et al. [22] and Carey et al. [8] analyzed the CSR in terms of auditing and reported that the CSR of their countries is related to ethical and opportunistic motivation, respectively, but they only showed the average characteristics and did not consider the firm's unique attributes. Carey et al. [8] divided the sample into state-owned enterprises (SOEs) and non-state owned enterprises (non-SOEs) and found that non-SOEs are more related to opportunistic CSRs, indicating that the characteristics of the individual firms affect CSR motivation and that they need to be considered in the CSR literature. This study meets this by using firm-level auditor information, EOM, and extending the literature. In particular, EOM has a big advantage in that it is easy to use as it is public information disclosed in the audit report.

Thirdly, the result of this study may imply that auditor, properly monitoring firms, evaluate CSP independently. It indicates the importance of auditor independence and ability as a CSP related information intermediary. EOM paragraphs include risk related factors such as litigation, going-concern opinions or significant transactions between insiders or affiliated firms, thus managers are not willing to include them and want to avoid them if possible. Therefore, the inclusion of EOM in audit reports may indicate that the auditors conduct auditing and provide audit reports independently. Thus, our result can be interpreted that auditors, who play a monitoring role well, do not accept high CSP as good without their own judgement.

Fourthly, this study offers useful policy implication. CSR for private interests of managers is accompanied by costs, which negatively affects the firm and the whole economy. In addition, unethical managers can adversely affect the financial information and the operation of the firm, which may ultimately result in huge losses for investors. Therefore, monitoring unethical managers is always a concern for regulators. Our findings show that EOM provides a clue for judging unethical managers, suggesting that regulators need to closely monitor firms with EOM paragraphs.

Additionally, with several accounting frauds, such as Daewoo Shipbuilding and Marine Engineering in 2015, the Korean government is conducting accounting reform to improve accounting transparency [45]. One of accounting reform measures requires auditors to add explanatory languages related to key audit matters in audit reports. This implies that governmental authorities recognize the importance of explanatory languages as useful information to users. This study shows that auditor information is also useful in CSR research with the hope that future CSR studies will be conducted from various perspectives using auditor information.

Finally, EOMs in audit reports reflect the high degree of expertise possessed by the auditors and can be regarded as an item directly related to the firm's sustainability, such as going-concern opinion. Therefore, the results of this study, in which the auditor positively evaluates the ethical characteristic of CSP only for firms to be sustainable in the future (without EOM), suggest that the auditors play an important role in evaluating sustainability.

Despite the above contributions and implications, our research has some limitations. First, this study only uses total CSR scores; thus, future researchers need to investigate the impact of EOM on CSP by using specific properties, such as soundness, fairness, social contribution, consumer protection, environmental management and employee satisfaction and identify which attribute the auditor is more responsive to. 
Secondly, this study only covers firm-years whose KEJI scores (CSP) are published and it can be difficult to generalize the findings. In addition, we used Korean listed firms with a unique business environment, including a business group called 'chaebol'. The KEJI score used as a proxy for CSP may not fully capture the firms' genuine CSP. Therefore, if the CSP is measured based on more samples from various aspects in the future and if future research investigates many other countries with varying degrees of economic development, institutions and cultures, it may be possible to obtain more meaningful results. It is also essential to examine unidentified institutional and financial factors to distinguish from opportunistic CSR in the future.

Finally, there may be a possibility of omitted variables in the research model, even if this study tries to address this through various control variables. We expect researchers to develop robust research model in the future. Additionally, we used slightly outdated 2011-2016 data due to the hand-collecting characteristic of the key variables (CSP and EOM). We believe that further research using expanded data will be beneficial to the generalization of our findings.

Author Contributions: The authors contributed equally to the manuscript. H.A.K. designed overall research framework and performed the literature review. N.C.J. participated in the design of the study and carried out statistical analysis. H.A.K. and N.C.J. drafted the manuscript and approved final draft. All authors have read and agreed to the published version of the manuscript.

Funding: This work was supported by the Hongik University new faculty research support fund.

Conflicts of Interest: The authors declare no conflict of interest.

\section{Appendix A}

Table A1. Variable Definitions.

\begin{tabular}{cc}
\hline Variable & Definition \\
\hline LNAH & The natural logarithm of audit hours \\
\hline CSP & CSR score released by the KEJI \\
\hline SIZE & The natural logarithm of total assets \\
\hline LEV & Total liabilities scaled by total assets \\
\hline BIG4 & Net income to beginning total assets \\
\hline ROA & Foreign ownership ratio \\
\hline FOR & 1 if the company experiences loss, 0 otherwise \\
\hline LAR & The sum of account receivables and inventories scaled by total assets \\
\hline LOSS & Cash flow from operations scaled by total assets \\
\hline CON & Book value divided by market value \\
\hline ARINV & Current assets divided by current liabilities \\
\hline CFO & Performance-matched discretionary accruals according to Kothari et al. [42] \\
\hline BTM & Total accruals divided by the total assets at the beginning year \\
\hline QR & 1 If firm includes emphasis of matter paragraph in audit report and 0 otherwise \\
\hline GRW & Sales growth ratio, which is the percentage of sales increase (decrease) divided by sales in previous year \\
\hline CHN & Tobin's the sum of the market value of equity and book value of debt deflated by the book value of assets \\
\hline EOM &
\end{tabular}




\section{References}

1. Chung, C.; Jung, S.; Young, J. Do CSR activities increase firm value? Evidence from the Korean market. Sustainability 2018, 10, 3164-3185.

2. Berman, S.L.; Wicks, A.C.; Kotha, S.; Jones, T.M. Does Stakeholder Orientation Matter? The Relationship Between Stakeholder Management Models and Firm Financial Performance. Acad. Manag. J. 1999, 42, 488-506.

3. Dhaliwal, D.S.; Li, O.Z.; Tsang, A.; Yang, Y.G. Voluntary Nonfinancial Disclosure and the Cost of Equity Capital: The Initiation of Corporate Social Responsibility Reporting. Account. Rev. 2011, 86, 59-100. [CrossRef]

4. Kim, Y.; Park, M.S.; Wier, B. Is Earnings Quality Associated with Corporate Social Responsibility? Account. Rev. 2012, 87, 761-796. [CrossRef]

5. Malik, M. Value-Enhancing Capabilities of CSR: A Brief Review of Contemporary Literature. J. Bus. Ethics 2015, 127, 419-438. [CrossRef]

6. Chung, J.; Cho, C.H. Current Trends within Social and Environmental Accounting Research: A Literature Review. Account. Perspect. 2018, 17, 207-239. [CrossRef]

7. Jensen, M.C.; Meckling, W.H. Theory of the firm: Managerial behavior, agency costs and ownership structure. J. Financ. Econ. 1976, 3, 305-360. [CrossRef]

8. Carey, P.; Liu, L.; Qu, W. Voluntary corporate social responsibility reporting and financial statement auditing in China. J. Contemp. Account. Econ. 2017, 13, 244-262. [CrossRef]

9. Lee, H.Y.; Yi, H.; Yun, Y. Empirical Archival Audit Research in Korea: A Primer-Commissioned Survey Paper for the Editorial Board of Korean Accounting Review. Korean Account. Rev. 2016, 41, 311-376.

10. Brown-Liburd, H.; Zamora, V.L. The Role of Corporate Social Responsibility (CSR) Assurance in Investors' Judgments When Managerial Pay is Explicitly Tied to CSR Performance. Audit. J. Pract. Theory 2015, 34, 75-96. [CrossRef]

11. Czerney, K.; Schmidt, J.J.; Thompson, A.M. Does Auditor Explanatory Language in Unqualified Audit Reports Indicate Increased Financial Misstatement Risk? Account. Rev. 2014, 89, 2115-2149. [CrossRef]

12. Financial Supervisory Service (FSS). An analysis of audit reports for public companies in 2016. Available online: http://www.fss.or.kr/fss/kr/promo/bodobbs_view.jsp?seqno=20665 (accessed on 1 November 2018).

13. De Fond, M.; Zhang, J. A review of archival auditing research. J. Account. Econ. 2014, 58, 275-326. [CrossRef]

14. Beaulieu, P.R. The effects of judgments of new clients' integrity upon risk judgments, audit evidence and fees. Audit. J. Pract. Theory 2001, 20, 85-100. [CrossRef]

15. Du, X.; Jian, W.; Zeng, Q.; Chang, Y. Do auditors applaud corporate environmental performance? Evidence from China. J. Bus. Ethics 2018, 151, 1049-1080. [CrossRef]

16. TheKoreaTimes. Firms Take Higher Social Responsibility Profile. Available online: http://www.koreatimes. co.kr/www/tech/2018/11/693_10234.html\# (accessed on 7 December 2019).

17. Schelleman, C.; Knechel, W.R. Short-term accruals and the pricing and production of audit services. Audit. J. Pract. Theory 2010, 29, 221-250. [CrossRef]

18. O'Keefe, T.B.; Simunic, D.A.; Stein, M.T. The Production of Audit Services: Evidence from a Major Public Accounting Firm. J. Account. Res. 1994, 32, 241-261. [CrossRef]

19. Czerney, K.; Schmidt, J.J.; Thompson, A.M. Do Investors Respond to Explanatory Language Included in Unqualified Audit Reports? Contemp. Account. Res. 2019, 36, 198-229.

20. Dhaliwal, D.S.; Radhakrishnan, S.; Tsang, A.; Yang, Y.G. Nonfinancial Disclosure and Analyst Forecast Accuracy: International Evidence on Corporate Social Responsibility Disclosure. Account. Rev. 2012, 87, 723-759. [CrossRef]

21. Sun, W.C.; Huang, H.W.; Dao, M.; Young, C.S. Auditor selection and corporate social responsibility. J. Bus. Financ. Account. 2017, 44, 1241-1275. [CrossRef]

22. Chen, L.; Srinidhi, B.; Tsang, A.; Yu, W. Audited Financial Reporting and Voluntary Disclosure of Corporate Social Responsibility (CSR) Reports. J. Manag. Account. Res. 2016, 28, 53-76. [CrossRef]

23. Moon, J.; Shen, X. CSR in China Research: Salience, Focus and Nature. J. Bus. Ethics 2010, 94, 613-629. [CrossRef]

24. Du, X. Is Corporate Philanthropy Used as Environmental Misconduct Dressing? Evidence from Chinese Family-Owned Firms. J. Bus. Ethics 2015, 129, 341-361. 
25. Hoitash, R.; Markelevich, A.; Barragato, C.A. Auditor fees and audit quality. Manag. Audit. J. 2007, 22, 761-786. [CrossRef]

26. Hope, O.K.; Kang, T.; Thomas, W.B.; Yoo, Y.K. Impact of excess auditor remuneration on the cost of equity capital around the world. J. Account. Audit. Financ. 2009, 24, 177-210. [CrossRef]

27. Krauß, P.; Pronobis, P.; Zülch, H. Abnormal audit fees and audit quality: initial evidence from the German audit market. J. Bus. Econ. 2015, 85, 45-84. [CrossRef]

28. Caramanis, C.; Lennox, C. Audit effort and earnings management. J. Account. Econ. 2008, 45, 116-138. [CrossRef]

29. Cho, E.; Chun, S. Corporate social responsibility, real activities earnings management, and corporate governance: evidence from Korea. Asia-Pac. J. Account. Econ. 2016, 23, 400-431. [CrossRef]

30. Wiśniewski, M. CSR risk management. Forum Sci. Oeconomia 2015, 3, 17-24.

31. Story, D.; Price, T.J. Corporate social responsibility and risk management. J. Corp. Citizsh 2006, $22,39-51$. [CrossRef]

32. Jung, N.C.; Kim, H.A.; Choi, J.W. The audit report lag by the type of emphasis of matter in audit report. Korean Manag. Rev. 2019, 48, 683-714. [CrossRef]

33. Yu, J.; Lee, S. The Impact of Greenhouse Gas Emissions on Corporate Social Responsibility in Korea. Sustainability 2017, 9, 1135-1149. [CrossRef]

34. Lee, W.J.; Choi, S.U. Effects of Corporate Life Cycle on Corporate Social Responsibility: Evidence from Korea. Sustainability 2018, 10, 3794. [CrossRef]

35. Cho, M.; Ki, E.; Kwon, S.Y. The Effects of Accruals Quality on Audit Hours and Audit Fees. J. Account. Audit. Financ. 2017, 32, 372-400. [CrossRef]

36. Stein, M.T.; Simunic, D.A.; O'Keefe, T.B. Industry differences in the production of audit services. Audit. J. Pract. Theory 1994, 13, 128-142.

37. Simunic, D.A.; Stein, M.T. Impact of litigation risk on audit pricing: A review of the economics and the evidence. Audit. J. Pract. Theory 1996, 15, 119-134.

38. Ashbaugh, H.; LaFond, R.; Mayhew, B.W. Do Nonaudit Services Compromise Auditor Independence? Further Evidence. Account. Rev. 2003, 78, 611-639. [CrossRef]

39. Deis, D.R.; Giroux, G. The effect of auditor changes on audit fees, audit hours, and audit quality. J. Account. Public Policy 1996, 15, 55-76. [CrossRef]

40. Petersen, M.A. Estimating Standard Errors in Finance Panel Data Sets: Comparing Approaches. Rev. Financ. Stud. 2009, 22, 435-480. [CrossRef]

41. Reichelt, K.J.; Wang, D. National and Office-Specific Measures of Auditor Industry Expertise and Effects on Audit Quality. J. Account. Res. 2010, 48, 647-686. [CrossRef]

42. Kothari, S.P.; Leone, A.J.; Wasley, C.E. Performance matched discretionary accrual measures. J. Account. Econ. 2005, 39, 163-197. [CrossRef]

43. Jung, N.C.; Kim, H.A. The Effect of Listing Period on Corporate Social Responsibility: Evidence from Korea. Sustainability 2019, 11, 2447-2461. [CrossRef]

44. Craswell, A.T.; Francis, J.R.; Taylor, S.L. Auditor brand name reputations and industry specializations. J. Account. Econ. 1995, 20, 297-322. [CrossRef]

45. Financial Supervisory Service (FSS). Accounting Supervision Issues and Future Directions for Supervision. Available online: http://acct.fss.or.kr/fss/acc/bbs/view.jsp?url=/fss/ac/1295497768377\&bbsid=1295497768377\& $\mathrm{idx}=1577088596770$ \&num $=294$ (accessed on 30 December 2019).

(C) 2020 by the authors. Licensee MDPI, Basel, Switzerland. This article is an open access article distributed under the terms and conditions of the Creative Commons Attribution (CC BY) license (http://creativecommons.org/licenses/by/4.0/). 